\begin{tabular}{|c|c|}
\hline $\begin{array}{l}\text { 研究者育成 } \\
\text { 成果報告 }\end{array}$ & $\begin{array}{c}\text { ホソカワ粉体工学振興財団年報 } \\
\text { Hosokawa Powder Technology Foundation ANNUAL REPORT }\end{array}$ \\
\hline
\end{tabular}

\title{
15507
}

\section{機能性粉体調製による難水溶性化合物の溶解性改善 \\ Improvement in Solubility of Poorly Water-soluble Drugs by Preparation of Functional Powder}

\author{
援助対象者 Scholarship Student: 藤森 美季 Miki FUJIMORI \\ 大阪薬科大学 薬学博士課程 1 年 \\ Osaka University of Pharmaceutical Sciences, PhD Student (D1) \\ E-mail: e16052@gap.oups.ac.jp
}

\begin{abstract}
研究指導者 Academic Leader： 戸塚 裕一 Yuichi TOZUKA
教授, Professor

E-mail: ytozuka@gly.oups.ac.jp
\end{abstract}

\section{成 果 の 概 要}

\section{1. 背景}

現在，有用な薬理効果を持った多くの医薬品 候補化合物が合成されており, 創成される化合 物の多くが難水溶性薬物となる。難水溶性薬物 は消化管での溶解性が低いため, 十分な薬理効 果を示す薬物量が体内に吸収されないことが問 題となっている.

我々はこれまで, 難水溶性薬物と糖転移化合 物である $\alpha$-Glycosyl Stevia（Stevia-G）を溶液中 で混合し，それを噴霧乾燥することで糖転移化 合物と薬物とのナノコンポジットを形成させ, 薬物の溶解性が向上することを報告してきた ${ }^{[1]}$. さらに, 薬物と Stevia-Gとの系に三成分目と して界面活性剤を添加することで薬物の飛躍的 な溶解性向上が可能であると報告してきた ${ }^{[2]}$. しかしながら，3成分目である界面活性剂が薬 物溶解性改善に与える影響についての詳細は明 らかでない.

\section{2. 本研究の目的と意義}

本研究の目的は, Stevia-G と界面活性剂によ る薬物の溶解性改善機構を解明することであ る。これまでの検討において, Stevia-G は弱い 界面活性作用を示し，ミセル様の会合体を形成 することを明らかにされてきた ${ }^{[3]}$.そこで，混 合ミセルの相互作用を評価する方法として既に 適用されている Rubingh 式を, Stevia-G と界面 活性剂について適用し, 相互作用評価を行った。 さらに，等温滴定型熱測定法 (Isothermal Titration Calorimetry: ITC) を用いて Stevia-G と 界面活性剤間で生じる熱力学的パラメー夕を算 出し, 薬物の可溶化メカニズムの解明を試みた.

本研究による Stevia-G と界面活性剤による難 水溶性薬物の溶解性改善効果に加えて, Stevia-G と界面活性剤間の相互作用に関する熱 力学的な基礎的現象の理解は, 製薬. 食品会社 で問題となっている難水溶性有効成分の商品開 発への応用が期待される。 


\section{3. 研究成果}

本研究では, Stevia-G 及び陽イオン性界面活 性剂である 1-Dodecylpyridinium chloride（DPC） を使用し，可溶化機構の解明に取り組んだ.

\section{1 相互作用パラメータの算出}

Stevia-G と界面活性剂の相互作用パラメー夕 は，混合ミセル系の評価として一般的に使用さ れている Regular solution model の Rubingh 式 ${ }^{[4]}$ により算出した。なお，本実験での Critical micelle concentration (CMC) は, 最大泡圧法に よる界面張力により求めた。

Rubingh モデルでは 2 種の界面活性剂が相互 作用している場合，相互作用パラメータである $\beta$ の值が負を示すことが報告されている ${ }^{[4]}$. Table 1 に本実験により得られた各種相互作用 パラメータを示す。 $\beta$ の值は，すべて負の值を

Table $1 \mathrm{CMC}$ values as a function of the mole fraction of DPC.

\begin{tabular}{cccc}
\hline$\alpha_{\mathrm{DPC}}$ & ${ }^{\text {ideal }} C_{\mathrm{cmc}}(\mathrm{mM})$ & ${ }^{\text {expt }} C_{\mathrm{cmc}}(\mathrm{mM})$ & $\beta$ \\
\hline 0 & 10.0 & 10.0 & 0 \\
0.05 & 10.2 & 5.95 & -7.77 \\
0.1 & 10.5 & 5.53 & -7.75 \\
0.2 & 11.0 & 5.77 & -7.34 \\
0.5 & 12.9 & 4.54 & -10.00 \\
0.8 & 15.6 & 9.54 & -12.58 \\
1 & 18.1 & 18.1 & 0 \\
\hline
\end{tabular}

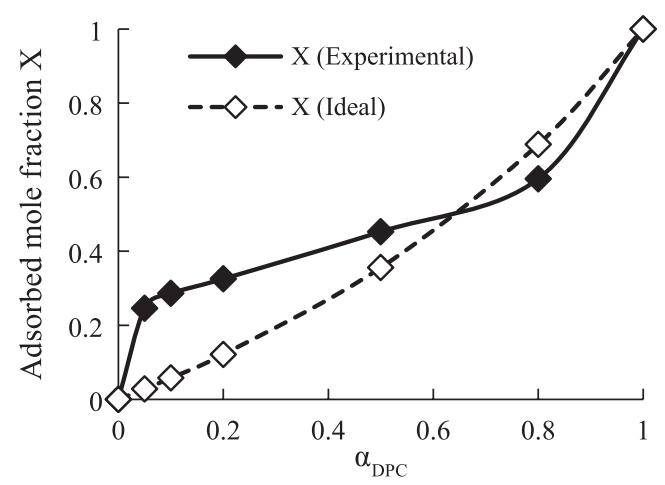

Fig. 1 Values of the mole fraction of DPC in mixed micelle $(X)$.
示し, Stevia-G と DPCの分子間に打ける相互 作用が示唆された。また，2種の界面活性剂が 全く相互作用していないと仮定したときの CMC（Ideal, $\beta=0)$ と実際に測定したCMCを 比較すると実測值は理想值を大きく下回った。 これは，検討したすべての DPC モル分率にお いて, Stevia-G と DPC の間で相互作用に基づ く混合ミセル様の複合体が形成されていること を示唆する。

Fig. 1 は Stevia-G と DPCによる混合ミセル様 構造中に扔けるDPCのモル分率 $(X)$ を示す. 本来, 界面活性剂の添加量に比例して増加する モル分率 $X$ が, 実測值では $0.2 \sim 0.6$ を示し, 添加した組成比とは異なった比での複合体形成 の可能性が示唆された.

3.2 ITC による Stevia-G 界面活性剂間の相 互作用評価

等温滴定型熱測定法 (Isothermal Titration Calorimetry: ITC) による測定では, $25^{\circ} \mathrm{C}$ 条件 下に扮いてセル $(200 \mu \mathrm{L})$ に精製水もしくは Stevia-G 溶液を充填し，シリンジ $(40 \mu \mathrm{L})$ か ら試料を $0.5 \mu \mathrm{L}$ 毎で滴下し評価した。相互作 用の評価に用いたギブスエネルギー変化 $(\Delta G)$ 及びエントロピー変化 $(\Delta S)$ は, 測定によっ て得られた $\mathrm{CMC}$ 及び, 熱量変化 $(\Delta H)$ から 偽層分離モデルを利用して算出した。

ITCを用いて Stevia-GとDPC 間に扔ける相 互作用の評価を行った。ITCのセルに蒸留水も しくは Stevia-G 溶液を充填し DPC 溶液を滴下

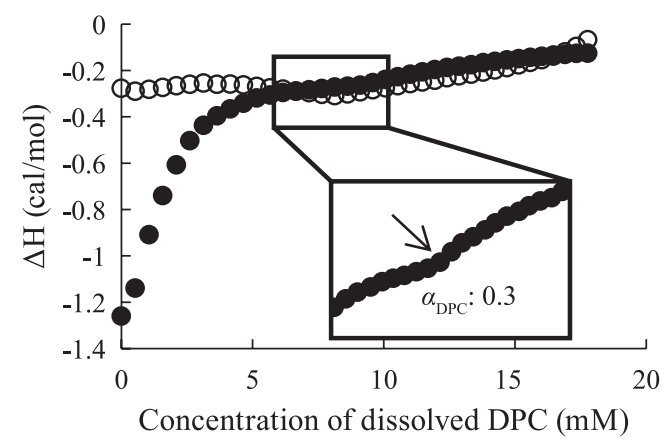

Fig. 2 ITC curves obtained at $25^{\circ} \mathrm{C}$ for DPC solution titrated into water $(\bigcirc)$ and into stevia-G solution( 
した結果を Fig. 2 に示す. Fig. 2 より両プロッ トの $\Delta H$ の違いは Stevia-G と界面活性剤の相互 作用を表している ${ }^{[5]}$. また, DPC モル分率が 0.3 において得られたプロットに変曲点が観察され たことから, Stevia-G と界面活性剂の混合ミセ ル様の構造が変化した可能性が示唆された.

続いて, ITCを用いて熱力学的パラメータの 算出を行った。求めた $\Delta H, \Delta G, \Delta S$ の值を Table 2 に示す。異なるモル分率で調製した Stevia-G と DPC の混合溶液においては, $\Delta H$ の 值が 0.2 と 0.5 の間を境に正負が変化しており, Fig. 2 の Stevia-G 存在下での DPC 添加時に生 じた変曲点が観察された DPC モル分率が 0.3 であったこととあわせて, ここでの構造変化の 可能性が示唆された．また $\Delta G$ の值はすべての 比でマイナスを示し, 特に 0.5 のときに最も自 発的に混合ミセル様の構造体を形成することが 明らかとなった。 また， $\Delta S$ はすべてのモル分 率で正の值を示しミセル形成には疎水性相互作 用が寄与していると示唆された。

\section{3 溶解度試験}

モデル薬物として BCS Class II に属する酸性 医薬品である Mefenamic Acid（MFA）と塩基性 医薬品であるClotrimazole（CTZ）を用いた。 薬物の溶解度は, 薬物を $50 \mathrm{mg}$ として精製水 $25 \mathrm{~mL} ， 37^{\circ} \mathrm{C}$ ，で 24 時間のインキュベーショ ンを行い, 平衡溶解度に達した後, HPLCにて

Table 2 Contributions of thermodynamic parameters of micellization of Stevia-G and surfactant.

\begin{tabular}{cccc}
\hline$\alpha_{\mathrm{DPC}}$ & $\begin{array}{c}\Delta H_{\text {mic }} \\
(\mathrm{kJ} / \mathrm{mol})\end{array}$ & $\begin{array}{c}\Delta G_{\text {mic }} \\
(\mathrm{kJ} / \mathrm{mol})\end{array}$ & $\begin{array}{c}\Delta S_{\text {mic }} \\
(\mathrm{J} / \mathrm{K} \cdot \mathrm{mol})\end{array}$ \\
\hline 0 & -1.71 & -21.2 & 65.5 \\
0.05 & -0.94 & -24.8 & 80.1 \\
0.1 & -0.65 & -24.2 & 79.0 \\
0.2 & -0.71 & -24.5 & 79.9 \\
0.5 & 0.47 & -25.4 & 86.7 \\
0.8 & 1.30 & -23.3 & 82.5 \\
1 & 3.22 & -20.2 & 78.7 \\
\hline
\end{tabular}

測定した。 各添加剂添加時の溶解度は, 薬物 $50 \mathrm{mg}$ に対し Stevia-G/DPCの総物質量を固定 し各モル比で添加し同様の条件でインキュベー ションを行った.

各 DPC モル分率での溶解度試験の結果を Fig. 4 に示す. その結果 MFA, CTZともに DPC 単独及び Stevia-G 単独よりも2 成分を混 合した際に顕著に溶解度の向上を示した.また,

Stevia-G, DPC を DPC モル分率 0.8 で添加した 際に最も溶解性の改善効果が高いことが示され た。これは, 薬物溶解度が糖転移ステビアと界 面活性剂の相互作用だけでなく, 混合ミセルと 薬物との相互作用も寄与していることからこの ような結果になったと考えられる。

\section{4 結論}

Stevia-G と DPC は, 疎水性相互作用によって 混合ミセルを形成しており, DPC モル分率が 0.5

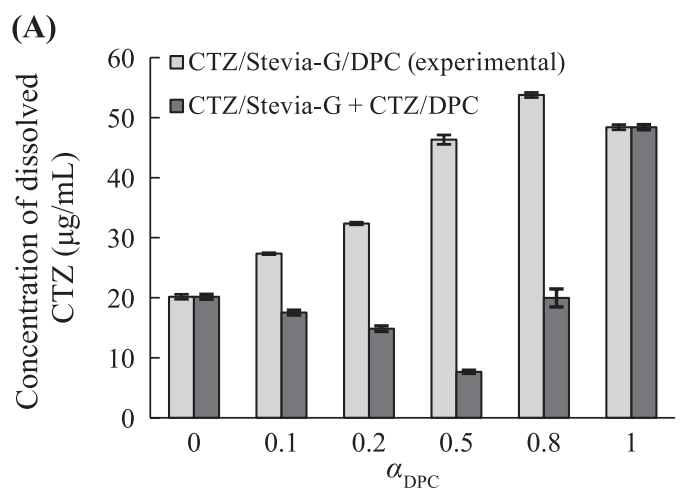

(B)

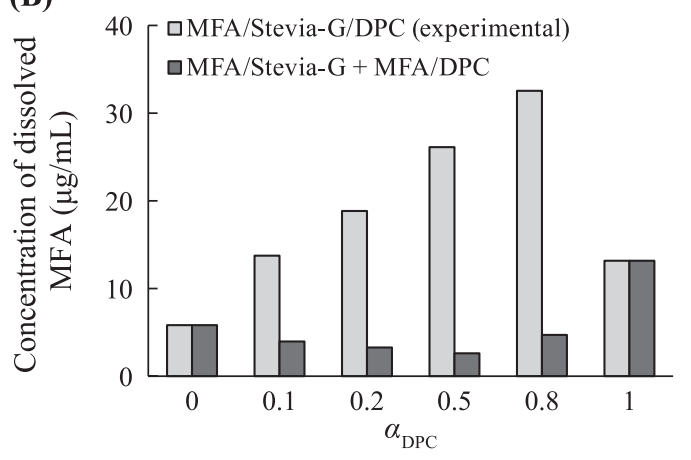

Fig. 3 (A), (B) Difference in concentration of dissolved drugs between ternary system and the sum of binary system as a function of the mole fraction of DPC. 
のとき最も CMC が低下する。また難水溶性薬 物の可溶化効果は DPC 単独及び Stevia-G 単独 よりも2 成分を混合した際に，顕著に向上する ことを明らかにした。この Stevia-G と界面活 性剂の溶解性改善技術を用いて高溶解性の機能 性粉体を調製することは, 医薬品及び健康食品 開発における貢献が期待される。

\section{参考文献}

[1] Uchiyama H., Tozuka Y., Asamato F., Takeuchi H.,

\section{論文発表}

1. M. Fujimori, K. Kadota, Y. Tozuka., Mixed Micelle System Produced by Interaction Between Transglycosylated Stevia and an Ionic Surfactant Improves Dissolution Profile of Mefenamic Acid, Journal of Pharmaceutical Sciences, 106 (2017) 1117-1123.

\section{口頭・ポスター発表}

1. 藤森 美季, 内山博雅, 門田和紀, 戸塚 裕一,

Euro. J. Pharm. Sci. 43 (2011) 71-77.

[2] Uchiyama H., Tozuka Y., Nishikawa M., Takeuchi H., Int. J. Pharm. 428 (2012) 183-186.

[3] Zhang J., Higashi K., Ueda K., Kadota K., Tozuka Y., Limwikrant W., Yamamoto K., Moribe K., Int. J. Pharm. 465 (2014) 255-261.

[4] Kakehashi R., Shizuma M., Yamamura S., Takeda T., J. Colloid Interface Sci. 279 (2004) 253-258.

[5] Watson L., César B., Kam C. T., Biochimica et Biophysica Acta 1860 (2016) 999-101.

“機能性食品添加剤と界面活性剂による混合 ミセルの熱力学的評価” 粉体工学会 2016 年 度 秋期研究発表会（Tokyo, November 29-30, 2016) BP-3.

2. M. Fujimori, K. Kadota, Y. Tozuka., "Improvement in dissolution profile of poor water-soluble compounds using mixed micelle formation between transglycosylated stevia and ionic surfactant", 1st Food Chemistry Conference (Amsterdam, Netherlands, October 30-November 1, 2016) P2.1.11. 